Nino Serdarević ${ }^{1}$

Ajla Muratović-Dedić

\title{
FINANCIAL REPORTING INCENTIVES: TAXATION AND EXTERNAL FINANCING NEED
}

\begin{abstract}
Earnings management literature extensively explores tax regime and debt contracting as possible incentives in financial reporting. Firms engage with aggressive financial reporting to bias earnings in periods when the need for external financing increases. Contrary to this, the tax burden represents incentive for more conservative reporting.
\end{abstract}

We argue that the level of firm's financial reporting aggressiveness is not constant but rather floating from period to period, directly affecting the quality of financial reports. We assume that firm's management on its own discretion determines the level of conservatism, balancing between these two incentives. The prevailing of two incentives, the need for external financing and the tax burden, determines the level of conservatism in particular reporting period.

We hypothesised that the reduction in tax burden incentive overcomes the debt contracting incentive in the years of decreasing external financing need, implying more conservative accounting to balance between economic and taxable income. The total accruals are used as a measure of earnings management reflected to working capital accruals.

The data analysis conducted on financial reports of 297 firms in the time-series of five years shows a significant correlation between total accruals, external financing needs and difference between economic and taxable income.

Key words: Accounting conservatism, Discretionary accruals, Earnings management, External financing need, Tax burden

JEL: $M 42$

1 Associate professor, Faculty of Economics University of Zenica, e-mail: nino.serdarevic@ef.unze.ba 2 Assistant professor, Faculty of Economics University of Zenica, e-mail: ajla.muratovic@gmail.com 


\section{INTRODUCTION}

The accounting-based performance measurement represents one way of mitigating agency problems in debt contracting. Firms' have incentive to bias earnings, disclosed in the financial reports, and shift the risk of potential losses to borrowers. The incentive to engage with aggressive financial reporting may be especially pronounced in case the debt contract grounds on accounting-based covenants. Accounting conservatism is believed to improve contract efficiency by lowering informational asymmetry between the firm and the borrower. Vice versa, aggressive financial reporting is believed to be less informative as it does not anticipate systemic risks.

Another influence on financial reporting relate to the tax regime, bearing in mind that the taxation reduces resources available to the firm. The level of taxation burden is expected to correlate to the conservatism. Dai et al. (2008) predict that in the presence of capital gains taxes, the net effect on asset prices is ambiguous, while the relative strength of the capitalization effect and the lock-in effect depends on the time period surrounding a tax rate change and firm characteristics such as dividend policy, growth potential, and the percentage of tax-sensitive individual ownership.

Firms may decide not to evaluate accounts receivable, in case that tax reporting requires correction for obscure expenditure. Instead, assets are valued based on tax rules, not on economic values, so financial reporting is aggressive. We then assume that firms tend to be aggressive for both financial reporting and tax reporting purposes, but prior research argue that the firms disclosing particular differences between tax and book values of income and assets are subject to greater scrutiny from regulators (Badertscher et al., 2009).

In the countries where financial reporting and tax reporting differ it is expected that the taxes may represent the incentive for firms' financial reporting. This difference is expected to be visible in the difference between book and tax income. Since the tax is reducing resources available to the firm, the financial reporting tends to be less aggressive and conditional conservatism is more pronounced. Bushman and Piotroski (2006) argue that the country's conditional conservatism level is directly affected by the tax regime, as well as institutional structures and political economy.

This study provides an evidence on the association between conditional conservatism and external financing needs against anticipated tax sheltering activities in the economy with rather weak legal enforcement and widely spread use of accounting-based covenants in debt contracting, proposing that the conditional conservatism may rather not reduce the cost of debt with the diminishing role of accounting in the debt contracting. 


\section{Literature Review}

Devine (1963) defines accounting conservatism as a wisdom of anticipating no profits and provision for all possible losses and a conservative behaviour as arousing lower average expectations of goals fulfilment than alternative measuring and reporting actions.

Conservatism is sometimes connected to prudence as accounting principle with German origin (Ball \& Shivakumar, 2005). Maltby (2000) argues that the term prudence preserved meaning as moral behaviour or virtue of accountants, in contrast to the term conservatism that started to gain meaning as a part of creative accounting at the end of the nineteenth century. He points out that the special characteristic of conservatism, which distinguished it from the earlier understanding of accounting prudence, was to deliberate understatement of profit and assets.

Prior literature extends the view arguing that the book value of earnings reflects outdated information. Inspired by efficient market hypothesis authors accepted opinion that all proxies based on this accounting information can be enhanced with inclusion of market data as returns. (Ahmed, 1994). The difference between book and market value of equity consequently is represented in the valuations of firm's earnings. Following this rationale, Basu (1997) introduces new proxy, asymmetric timeliness of earnings. Conservatism then represents the degree of current economic gains or losses within current accounting income.

Watts (2003) defines conservatism as a characteristic of an accrual accounting system that captures the notion that the system requires stronger verification to recognize gains than losses resulting in the understatement of net assets and accumulated earnings. He argues that the existence and persistence of conservatism in accounting is generated by asymmetric loss functions associated with the economic determinants of conservatism, namely contracting, litigation, regulation and taxation. This is well explored in prior literature and pinned under the term conditional conservatism.

The literature suggests that conditional conservatism increases the efficiency of debt contracting by accelerating the violation of accounting-based covenants and transferring control rights from shareholders to creditors. (Zhang 2008)

The level of accounting conservatism may be considered from two perspectives on the accounting information function, valuation perspective where the accounting information is primarily used by decision-makers to determine the market value of equity and contracting perspective where information is used for contracting purposes (Ruch, 2015).

According to some authors, conservatism is considered as one of desirable earnings attribute, together with accrual quality, persistence, predictability, smoothness, value 
relevance, timeliness, by one-part research stream (Francis et al., 2004; Ball et al., 2000; Ball \& Shivakumar, 2006). Qiang (2007) argues that the conditional conservatism improves contracting efficiency where the firm litigation induces both conditional and unconditional conservatism, suggesting that both forms help avoid investor litigation against firms. He also believes that the regulation induces unconditional conservatism, indicating that this form helps prevent regulatory intervention.

Recent studies note that some proposed explanations do not apply to both forms. Basu (2005) suggests that taxation is likely to generate unconditional conservatism. Ball and Shivakumar (2005) argue that contracting generates conditional conservatism, which is partially supported by Ball et al.'s (2005) finding on debt contracting.

Ball and Shivakumar (2005) argue that conditional conservatism improves contracting efficiency by disclosing net present value projects that may trigger debt covenant violations. Guay and Verrecchia (2006) believe that conservatism also forgoes positive net present value projects and retains unnecessary capital within a firm, thereby reducing contracting efficiency.

The role of regulatory frameworks are also believed to play role in usefulness of conservatism. $\mathrm{Li}$ (2015) proposes that the conditional conservatism may increase the efficiency of debt contracting by accelerating the violation of accounting-based covenants and transferring control rights from shareholders to creditors, having effect on the cost of debt in countries where accounting-based covenants are more widely spread. In its cross-country study, he argues that a higher level of a country's conservative reporting system leads to lower cost of equity and debt capital. He interprets the conclusion that the observed conditional conservatism level in a country is an equilibrium outcome balancing various institutional forces and deviating from such level may be costly and difficult in the short run.

Many authors argue that the tax sheltering represents an incentive for accounting conservatism. Qiang (2007) argues that the taxation induces unconditional conservatism, indicating that this form is preferable in deferring taxes. Shackelford and Shevlin (2001) find that firms exhibit two behaviours. First, tax minimizing strategies often result in lower book income due to book-tax conformity. Second, large book-tax differences incentivise firms to be less conservative in financial reporting when reducing taxable income.

The corporate tax avoidance is well explored in previous studies (Slemrod, 2004; Chen and Chu, 2005; Crocker and Semrod, 2005; and Desai et al., 2007). Frank et al. (2009) find that tax aggressiveness is positively associated with aggressive financial reporting, reflecting earning management practices. 
Balancing between two incentives, contracting purposes and tax reporting, may represent managerial incentive for balancing the level of financial reporting aggressiveness and disclosed earnings in particular period or across more periods. Jones (1991) elaborated how managers face conflicting financial reporting incentives and choose incentive in their best interest. Dechow and Skinner (2000) suggest further research on earnings management to focus on managerial incentives. Zhang (2004) proposes research in earnings behaviour pertaining to investment decisions. Also, financial reporting behaviour change is associated with the debt contracting application motivation (Muratovic-Dedic and Serdarević, 2017). Hanlon and Heitzman (2010) believe that the tax related research in accounting may explore the theory of corporate tax avoidance, trade-offs and relations between financial reporting and tax reporting incentives. García Lara et al. (2005) point out that in European continental countries managers have prevailing incentives to decrease earnings in order to reduce tax, dividends and others motivations.

\section{Hypothesis Development}

The external financing need as a firm's incentive to accounting conservatism is observed through the contracting covenants grounding on accounting numbers. Ball et al. (2008) argue that the early recognition of losses can detect covenant violation in a timelier manner and lead to timely triggering of lenders' contractual rights to veto major decisions by loss-making managers. This is believed to lead to the erosion of debt quality through risky new investments and acquisitions, borrowing, dividends and stock repurchases.

The external financing need is based on the model introduced by Demirguc-Kunt and Maksimovic (1998) and further explored in relation to accounting conservatism by Kang et al. (2015), where the estimation of the firm's constrained growth rate is based on the percentage of revenue.

$E F N_{t}=g_{t} \times A_{t}-\left(1+g_{t}\right) \times E_{t} \times b_{t}$

Where

EFN is the firm's external financing need

gt is the firm's growth (measured by sales growth),

At is the firm's total assets,

Et is earnings after interest and taxes

bt is the proportion of earnings retained for reinvestment. 
Corporate tax burden is another segment of our analysis. We represent the tax burden in the current year as the ratio of taxable income and economic income. The taxable income is calculated based on the profit tax related obligation in the current year and the earnings before taxes disclosed in financial reports represent an economic income.

TAXit $=\mathrm{TAXOt} /(\mathrm{EBTt} * 0,1)$

Where

TAXo is the firm's corporate tax obligation in current period,

EBTt represents earnings before taxes in current period.

We argue that the firm may act in more aggressive financial reporting in period of high or increasing external financing needs and apply more conservative accounting choices when the need is met and assume that the tax burden may represent prevailing incentive in periods of stagnating or decreasing need for external financing.

This argument is based on the assumption ( $\mathrm{Li} \mathrm{2015)} \mathrm{that} \mathrm{creditors} \mathrm{protect} \mathrm{themselves}$ through binding contracts based on a series of performance measures in periodic financial reports, bearing the downside risks and facing limited upside potentials and thereby favor a conservative financial reporting system to minimize the default risk (Zhang 2008). Li (2015) argues that the limited upside potential of debt claims, influences creditors to have less incentive to require managers to recognize good news timely, especially when the firm value is far above the face value of the debt. The supportive evidence is given by Guay and Verrecchia (2007) who argue that conditional conservatism may also reduce the cost of capital by reducing the discount rate that market applies to firm value in the presence of uncertainty.

Givoly and Hayn (2000) used sign and magnitude of accruals as indication of conservatism degree. Further, Dechow et al. (2012) pointed out conservatism relation to earnings management and presented comparison for widely used earnings management models based on discretionary accruals. The authors argue that there is reversal of earnings management reflected to working capital accruals and that represents rather novel approach. We use this model of employed non cash working capital accruals as a measure of accruals where:

TACCit $=(\Delta$ CAit $-\Delta$ Cit $-\Delta$ CLit $+\Delta$ STDit - Depit $) /$ At -1

Where:

CA represents current assets,

$\mathrm{C}$ represents cash,

CL represents current liabilities,

STD represents debt included in current liabilities,

A represents total assets. 
Hypothesis: The level of applied accounting conservatism is strongly positively associated with the external finance need and economic earnings.

Reduction in tax burden incentive then overcomes the debt contracting incentive in the years of decreasing external financing need, implying more conservative accounting to balance between economic and taxable income; and vice versa.

We use the following regression model to estimate the impacts of tax burden and external financing need on conditional conservatism:

TACC $_{i t}=\alpha_{i}+\beta_{1} E F N_{t}+\gamma_{1} T A X_{t}+\varepsilon+\varepsilon_{i t}$

In order to control obtained results we included control variable size in estimation. Following previous literature, firms' size is represented as natural logarithm of firms' assets.

$T A C C_{i t}=\alpha_{i}+\beta_{1} E F N_{t}+\gamma_{1} T A X_{t}+$ Size $+\varepsilon+\varepsilon_{i t}$

Every firm is special and has different capacity and resources, so we employed fixed effects regression for previous estimations in order to capture intrafirm (within) variation over time.

\section{Sample and Descriptive Statistics}

The data is obtained from financial statements of firms established and operating in Federation of Bosnia and Herzegovina. Total sample descriptive statistics and correlations is provided in tables. Total sample included 1395 observations for 279 firms in the five-year time series. This data sample used in research is strongly balanced.

Table 1: Descriptive statistics

\begin{tabular}{crrrrr} 
Variable & \multicolumn{1}{l}{ Obs } & \multicolumn{1}{c}{ Mean } & Std. Dev. & \multicolumn{1}{c}{ Min } & \multicolumn{1}{c}{ Max } \\
\hline A & 1395 & 140 & 80.56873 & 1 & 279 \\
IND & 0 & & & & \\
YEAR & 1395 & 2012 & 1.414721 & 2010 & 2014 \\
EFN & 1373 & $5.70 \mathrm{e}+08$ & $9.85 \mathrm{e}+09$ & -3.226062 & $2.37 \mathrm{e}+11$ \\
TAX & 1395 & -7.836968 & 1368.215 & -21058 & 35578 \\
\hline TACC & 1395 & 398.8535 & 20995.24 & -405909 & 618327
\end{tabular}

To be included in the final sample, a firm must have financial statement data required for computing the research variables. So, the final sample included 1373 observations (financial statements). 


\section{Empirical Results}

The Pearson correlation matrix for variables employed within hypothesis testing subsection shows high correlation between total accruals and corporate tax burden (correlation coefficient is 0.62 ). In more concrete, there is a high correlation between discretionary accruals and the tax burden. The correlation between discretionary accruals and the external financing needs is somewhat lower (0.4427), similar as the correlation between external financing needs and the tax burden (0.3907).

Table 2: Correlations (obs=1373)

\begin{tabular}{crrr} 
& \multicolumn{1}{c}{ EFN } & \multicolumn{1}{c}{ TAX } & \multicolumn{1}{c}{ TACC } \\
\hline EFN & 1.0000 & & \\
TAX & 0.3907 & 1.0000 & \\
TACC & 0.4427 & 0.6224 & 1.0000 \\
\hline TACC & 1395 & 398.8535 &
\end{tabular}

Since every firm is unique with different characteristics and unique financial capacity, we are interested in intrafirm (within) variation over time, fixed effects regression is employed. In this research we consider fixed effects regression as best way to avoid potential omitted variable bias.

Table 3: Estimation of fixed-effect regression (obs=1373)

Fixed-effects (within) regression

Group variable: A
Number of obs $\quad=$

Number of groups =

Obs per group: $\min =$

overall $=0.4344$

$\operatorname{corr}\left(\mathrm{u} \_\mathrm{i}, \mathrm{Xb}\right)=-0.0004$

$\begin{array}{rlr}\text { avg } & = & 5.0 \\ \max & = & 5 \\ \mathrm{~F}(2,1094) & = & 420.28 \\ \text { Prob }>\mathrm{F} & = & 0.0000\end{array}$

\begin{tabular}{crrrrrr}
\hline tacc & \multicolumn{1}{c}{ Coef. } & \multicolumn{1}{c}{ Std. Err. } & \multicolumn{1}{c}{ t } & \multicolumn{1}{c}{ P> $|\mathbf{t}|$} & \multicolumn{2}{c}{ [99\% Conf. Interval] } \\
\hline efn & $5.07 \mathrm{e}-07$ & $5.30 \mathrm{e}-08$ & 9.58 & 0.000 & $3.71 \mathrm{e}-07$ & $6.44 \mathrm{e}-07$ \\
$\operatorname{tax}$ & 8.134217 & .3789035 & 21.47 & 0.000 & 7.156521 & 9.111913 \\
_cons & 180.948 & 431.4292 & 0.42 & 0.675 & -932.2821 & 1294.178 \\
\hline tacc & 1395 & 398.8535 & 20995.24 & -405909 & 618327 & \\
\hline
\end{tabular}

\begin{tabular}{ccc}
\hline sigma_u & 7.095 .5925 & \\
\hline sigma_e & 15943.569 & \\
\hline rho & .16532028 & (fraction of variance due to u_i) \\
\hline
\end{tabular}

$\mathrm{F}$ test all $\mathrm{u} \_\mathrm{i}=0$ :

$\mathrm{F}(276,1094)=0.99$

Prob $>F=0.5331$ 
Fixed effects estimation of equation (4) capture significant positive association of both independent variables with total accruals (Table 3.). Tax burden is positively associated with change in total accruals (8.134). So, stronger association is captured between tax burden and total accruals than external financing need and total accruals.

Table 4: Estimation of fixed-effect regression with control variable $\ln (\mathrm{TA})$

Fixed-effects (within) regression

Group variable: A $\begin{array}{ll}\text { Number of obs } & = \\ \text { Number of groups } & =\end{array}$

1373

277

$\begin{array}{ll}\text { R-sq: } & \text { within }=0.4358 \\ \text { between } & =0.3803 \\ \text { overall } & =0.4238\end{array}$

corr $\left(\mathrm{u} \_\mathrm{i}, \mathrm{Xb}\right)=-0.0513$
Obs per group: $\min =$

avg $=$

$\max =$

$\mathrm{F}(2,1094)$

Prob $>$ F

\begin{tabular}{ccccccr}
\hline tacc & Coef. & Std. Err. & \multicolumn{1}{c}{$\mathrm{t}$} & $\mathrm{P}>|\mathrm{t}|$ & \multicolumn{2}{c}{$[99 \%$ Conf. Interval] } \\
\hline efn & $4.97 \mathrm{e}-07$ & $5.33 \mathrm{e}-08$ & 9.32 & 0.000 & $3.60 \mathrm{e}-07$ & $6.35 \mathrm{e}-07$ \\
tax & 8.199685 & .3809618 & 21.52 & 0.000 & 7.216675 & 9.182694 \\
lnTA & -1756.11 & 1123.199 & -1.56 & 0.118 & -4654.341 & 1142.121 \\
\hline cons & 22068.3 & 14005.68 & 1.58 & 0.115 & -14071.05 & 58207.64 \\
\hline sigma_u & 7.469 .6895 & \multicolumn{7}{c}{} \\
\hline sigma_e & 15933.053 & \multicolumn{7}{c}{ Prob $>\mathrm{F}=0.5446$}
\end{tabular}

As it can be seen in Table 4. with results of estimation with included control variable representing firm's size, similar significant association are captured. So, these results confirm that reduction in tax burden overcomes debt contracting incentive.

\section{CONCLUDING REMARKS}

The literature suggests that the aggressive financial reporting is especially pronounced in cases where debt contracts ground on accounting-based covenants where conditional conservatism positively affects the efficiency of debt contracting. Many authors also believe that the taxation burden correlates to the conservatism where tax aggressiveness positively associates with aggressive financial reporting. While Qiang (2007) suggests that both conditional and unconditional conservatism help avoid investor litigation against firms, Ball and Shivakumar (2005) argue that conditional conservatism improves contracting efficiency by disclosing net present value projects that may trigger debt covenant violations and Ball and Shivakumar (2005) argue that contracting generates conditional conservatism. 
We examine managerial incentives to decrease earnings in order to reduce tax in persistent corporate tax regulation, controlling against fluctuating year-to-year external finance need. We hypothesized that the reduction in tax burden incentive overcomes the debt contracting incentive in years of decreasing external financing need, implying more conservative accounting to balance between economic and taxable income.

The analysis uses Dechow et al. (2012) discretionary accruals model of earnings management to capture managerial incentives. The external financing need is estimated using Kang et al. (2015) model that captures firm's constrained growth rate based on the percentage of revenue. The corporate tax burden influence was measured as a difference between reported earnings and taxable earnings. Our findings are robust, showing that the accounting conservatism highly correlates to the corporate tax burden, while the correlation between discretionary accruals and external financing need is somewhat lower.

The analysis has shown strong positive association of both observed variables, tax burden and external finance need, with the total reported accruals, as a measure of accounting conservatism.

Our findings show that firms exhibit earnings management practice to report higher earnings in periods of increasing need for external finance, aiming to improve the base for accounting-based covenants and to shift the risk to the borrower. However, the tax burden and anticipated outflow of resources embedded in the corporate tax, overcomes debt contracting as an incentive for more or less aggressive reporting.

\section{REFERENCES}

1. Ahmed, A. S. 1994. Accounting earnings and future economic rents: An empirical analysis. Journal of Accounting and Economics, 17(3), 377-400. DOI: https://doi.org/10.1016/0165-4101(94)90034-5.

2. Ball R. and L. Shivakumar. 2005. Earnings quality in U.K. private firms: Comparative loss recognition timeliness. Journal of Accounting and Economics 39: $83-128$.

3. Badertscher et al. 2009. Earnings management strategies and the trade-off between tax benefits and detection risk: to conform or not to conform? Accounting Review 84: 63-97

4. Basu, S. 1997. The conservatism principle and the asymmetric timeliness of earnings. Journal of Accounting and Economics 24: 3-37. 
5. Bushman, M. R., and J. D. Piotroski. 2006. Financial reporting incentives for conservative accounting: The influence of legal and political institutions, Journal of Accounting and Economics 42, 107-148.

6. Chen, K.-P. \& Chu, C. 2005. Internal control vs. external manipulation: A model of corporate income tax evasion, RAND Journal of Economics, 36, 151-164.

7. Crocker, K. \& Slemrod, J. 2005. Corporate tax evasion with agency costs. Journal of Public Economics, 89, 1593-1610. DOI: https://doi.org/10.1016/j.jpubeco.2004.08.003.

8. Dai, Z. et al. 2008. Capital Gains Taxes and Asset Prices: Capitalization or Lock-in?. The Journal of Finance 63: 709-742.

9. Dechow, P. M., Hutton, A. P., Kim, J. H., \& Sloan, R. G. 2012. Detecting earnings management: a new approach. Journal of Accounting Research, 50, 275-334. DOI: https://doi.org/10.1111/j.1475-679X.2012.00449.x

10. Demirguc-Kunt, A and V. Maksimovic. 1998. Law, finance, and firm growth. Journal of

11. Finance 3: 2107-2137.

12. Desai, M., Dyck, I. \& Zingales, L. 2007. Theft and taxes. Journal of Financial Economics, 84, 591-623.

13. Devine, C. T. 1963. The rule of conservatism reexamined. Journal of Accounting Research, 1(2), 127-138.

14. Francis, J., LaFond, R., Olsson, P. M., \& Schipper, K. 2004. Costs of equity and earnings attributes. The Accounting Review, 79(4), 967-1010.

15. Frank, M.M., Lynch, J.L. \& Rego, S.O. 2009. Are financial and tax reporting aggressiveness reflective of broader corporate policies? The Accounting Review, 84 (2), 467-496.

16. García Lara, J. M., García Osma, B., \& Mora, A. 2005. The effect of earnings management on the asymmetric timeliness of earnings. Journal of Business Finance \& Accounting, 32(3\&4), 691-726., DOI: 10.1111/j.0306-686X.2005.00610.x

17. Givoly, D. \& Hayn, C. (2000). The changing time-series properties of earnings, cash flows and accruals: Has financial reporting become more conservative?, Journal of Accounting and Economics, 29, 287-320. DOI: https://doi.org/10.1016/ S0165-4101(00)00024-0

18. Hanlon, M. \& Heitzman, S. 2010. A review of tax research. Journal of Accounting and Economics, 50, 127-178. 
19. Tony Kang, Gerald J. Lobo, Michael C. Wolfe. 2015. Accounting Conservatism and Firm Growth Financed by External Debt: The Role of Debt Maturity. Journal of Accounting, Auditing \& Finance.

20. Li, X. 2015. Accounting conservatism and the cost of capital: An international analysis. Journal of Business Finance and Accounting, 42, 555-582.

21. Muratovic-Dedic, A. \& Serdarevic, N. 2017. Financial Reporting Quality and Debt Contracting in Emerging Economy, International Journal of Academic Research in Accounting, Finance and Management Sciences, 7(4), 71-82.

22. Qiang, X. 2007. The Effects of Contracting, Litigation, Regulation, and Tax Costs on Conditional and Unconditional Conservatism: Cross-Sectional Evidence at the Firm Level. The Accounting Review 82: 759-796.

23. Shackelford, D. A., and T. Shevlin. 2001. Empirical tax research in accounting. Journal of Accounting and Economics 31: 321-387.

24. Slemrod, J. 2004. The economics of corporate tax selfishness. National Tax Journal, 57, 877-899. DOI: 10.3386/w10858

25. Wagenhofer, A. (2014) The role of revenue recognition in performance reporting, Accounting and Business Research, 44:4, 349-379, DOI: 10.1080/00014788.2014.897867

26. Watts, R. L. 2003. Conservatism in accounting part I: Explanations and implications. Accounting Horizons 17: 207-221

27. Zhang, J., 2008. The contracting benefits of accounting conservatism to lenders and borrowers, Journal of Accounting and Economics 45, 27-54. 
Nino Serdarević

Ajla Muratović-Dedić

\section{PODSTICAJI FINANSIJSKOG IZVJEŠTAVANJA: OPOREZIVANJE I POTREBA ZA EKSTERNIM FINANSIRANJEM}

\section{SAŽETAK}

U literaturi upravljanja zaradama u značajnom obuhvatu je obrađivana tematika porezne regulative i ugovaranja kao mogućih poticaja u finansijskom izvještavanju. Pravna lica se opredjeljuju za agresivno izvještavanje kako bi iskazala visoke zarade u periodima povećanih potreba za eksternim finansiranjem. Nasuprot tome, porezno opteréenje predstavlja poticaj konzervativnijem izvještavanju.

Mi tvrdimo da razina agresivnosti u finansijskom izvještavanju pravnog lica nije konstantna, već da oscilira iz perioda u period, direktno utječući na kvalitet finansijskih izvještaja. Pri tome pretpostavljamo da menadžment firme na osnovu sopstvene diskrecije određuje razinu konzervatizma balansirajući između dva navedena poticaja. Slijedom toga, pretpostavljamo da trenutna prevaga jednog od dva poticaja, potreba za eksternim finansiranjem i porezno opterećenje, određuju razinu konzervatizma u predmetnom izvještajnom periodu.

S tim u vezi, hipotetiziramo da smanjenje poticaja u vidu poreznog opterećenja prevazilazi poticaj ugovaranja u godinama smanjenja potreba za eksternim finansiranjem, što implicira konzervativnije računovodstvo koje se ogleda u uravnoteženju ekonomskih i oporezivih zarada. Ukupne akruale koristimo kao mjeru upravljanja zaradama, a koje se prevashodno ogleda u akrualima radnog kapitala.

Analiza podataka, provedena na finansijskim izvještajima 297 pravnih lica u vremenskoj seriji od pet godina, upućuje na značajnu korelaciju između ukupnih akruala, potreba za eksternim finansiranjem i razlika između ekonomskih i oporezivih zarada.

Ključne riječi: Računovodstveni konzervativizam, diskrecijski obračun, upravljanje prihodima, potrebe za eksternim finansiranjem, poresko opterećenje

JEL: $M 42$ 